\title{
Ghrelin-stimulation test in the diagnosis of canine pituitary dwarfism
}

\author{
S.F.M. Bhatti ${ }^{\mathrm{a}, *}$, S.P. De Vliegher ${ }^{\mathrm{b}}$, J.A. Mol ${ }^{\mathrm{c}}$, L.M.L. Van Ham ${ }^{\mathrm{a}}$, H.S. Kooistra ${ }^{\mathrm{c}}$ \\ ${ }^{a}$ Department of Small Animal Medicine and Clinical Biology, Faculty of Veterinary Medicine, \\ Ghent University, Salisburylaan 133, B-9820 Merelbeke, Belgium \\ b Department of Reproduction, Obstetrics, and Herd Health, Faculty of Veterinary Medicine, Ghent University, Salisburylaan 133, \\ B-9820 Merelbeke, Belgium \\ ${ }^{\mathrm{c}}$ Department of Clinical Sciences of Companion Animals, Faculty of Veterinary Medicine, Utrecht University, Yalelaan 8, NL-3508 TD Utrecht, \\ The Netherlands
}

Accepted 23 September 2005

\begin{abstract}
This study investigated whether ghrelin, a potent releaser of growth hormone $(\mathrm{GH})$ secretion, is a valuable tool in the diagnosis of canine pituitary dwarfism. The effect of intravenous administration of ghrelin on the release of GH and other adenohypophyseal hormones was investigated in German shepherd dogs with congenital combined pituitary hormone deficiency and in healthy Beagles.

Analysis of the maximal increment (i.e. difference between pre- and maximal post-ghrelin plasma hormone concentration) indicated that the GH response was significantly lower in the dwarf dogs compared with the healthy dogs. In none of the pituitary dwarfs, the ghrelin-induced plasma GH concentration exceeded $5 \mu \mathrm{g} / 1$ at any time. However, this was also true for 3 healthy dogs. In all dogs, ghrelin administration did not affect the plasma concentrations of ACTH, cortisol, TSH, LH and PRL .

Thus, while a ghrelin-induced plasma GH concentration above $5 \mu \mathrm{g} / 1$ excludes $\mathrm{GH}$ deficiency, false-negative results may occur. (C) 2005 Elsevier Ltd. All rights reserved.
\end{abstract}

Keywords: Dog; Growth hormone deficiency; Growth hormone secretagogue; Hyposomatotropism; Pituitary gland

\section{Introduction}

The secretion of growth hormone $(\mathrm{GH})$ is primarily under control of the central nervous system and is mainly regulated by the opposing effects of the hypothalamic hormones GH-releasing hormone (GHRH) and somatostatin (Plotsky and Vale, 1985). The existence of another, unknown factor involved in the control of somatotroph function has been hypothesized for several years. This was based on the observation that synthetic peptidyl and non-peptidyl compounds, named GH secretagogues (GHSs) or GH-releasing peptides (GHRPs), showed a strong GH-releasing effect (Bowers et al., 1977; Casanueva and Dieguez, 1999) and acted on a specific GHS-receptor (GHS-R), i.e. the GHS-R type 1a (Howard et al., 1996;

\footnotetext{
* Corresponding author. Tel.: +32 9 2647687; fax: +32 92647791.

E-mail address: Sofie.Bhatti@UGent.be (S.F.M. Bhatti).
}

McKee et al., 1997). The endogenous ligand of the GHS$\mathrm{R}$ type 1a has recently been purified from rat and human stomach (Kojima et al., 1999) and has also been identified in the fundus of the canine stomach (Tomasetto et al., 2001). This 28 -amino-acid peptide, ghrelin, has a unique structure with an $n$-octanoyl ester at its third serine residue which is crucial for its biological activity, at least in terms of GH release (Kojima et al., 1999; Bednarek et al., 2000; Date et al., 2000; Hayashida et al., 2001).

Ghrelin is a potent stimulator of GH release in several species such as humans (Arvat et al., 2000; Peino et al., 2000; Takaya et al., 2000), rats (Kojima et al., 1999) and dogs (Bhatti et al., 2002, 2005). In rats, the GH-releasing potency of ghrelin is similar to that of GHRH (Kojima et al., 1999), whereas in humans, ghrelin releases more GH than GHRH and the synthetic GHS hexarelin (Ghigo et al., 2001). In young dogs, ghrelin is a more potent stimulator of GH secretion than GHRH or GHRP-6 (Bhatti et al., 2005). However, the action of ghrelin and the 
synthetic GHSs is not exclusively confined to GH release. For example, in humans these substances also stimulate the secretion of prolactin (PRL), adrenocorticotrophic hormone (ACTH), and cortisol (Massoud et al., 1996; Takaya et al., 2000; Arvat et al., 2001; Ghigo et al., 2001). In rats, GHRP-6 activates the hypothalamic-pituitary-adrenal axis (Thomas et al., 1997). In contrast, ghrelin and GHRP-6 specifically release GH in young dogs (Bhatti et al., 2005).

Pituitary dwarfism or congenital GH deficiency in dogs is encountered most often in German shepherd dogs. In this breed, pituitary dwarfism is due to a simple, autosomal recessive inherited abnormality (Andresen and Willeberg, 1976). In contrast to disproportionate dwarfism caused by for example congenital hypothyroidism, the condition of congenital GH deficiency is characterized by profound proportionate dwarfism with retention of puppy coat or secondary hairs and lack of primary or guard hairs, and symmetrical alopecia. Intrapituitary cysts are often detected at a young age and gradually enlarge with time (Kooistra et al., 1998). Functionally, German shepherd dwarf dogs have a combined pituitary hormone deficiency. An absolute deficiency of GH, PRL and thyroid-stimulating hormone (TSH) is associated with an impaired release of gonadotrophins, whereas ACTH secretion is preserved (Hamann et al., 1999; Kooistra et al., 2000). The abnormality in these dwarfs is most likely caused by a mutation in a developmental transcription factor that precludes effective expansion of a pituitary stem cell after the differentiation of the corticotroph cells (Kooistra et al., 2000). To date, sequence analysis of genomic DNA from German shepherd dwarfs has not revealed causative mutations in candidate genes (Lantinga-van Leeuwen et al., 2000a,b; van Oost et al., 2002).

As ghrelin is a more potent stimulator of GH release than GHRH in young dogs, it may be useful for diagnostic purposes. We therefore investigated the effects of intravenous administration of ghrelin on the plasma concentration of GH in German shepherd dogs with pituitary dwarfism. Additionally, the plasma concentrations of ACTH, cortisol, TSH, PRL, and luteinizing hormone (LH) before and after ghrelin administration were measured in these dogs.

\section{Materials and methods}

\subsection{Dogs}

Six German shepherd dwarfs from different litters (four males and two females) referred to the Department of Clinical Sciences of Companion Animals, Utrecht University, because of an abnormal hair coat and proportionate growth retardation were used in this study. The mean age at presentation was 12 months (range 9-21 months) and the mean body weight was $9.6 \mathrm{~kg}$ (range $7.5-14.0 \mathrm{~kg}$ ).

The results of the pituitary dwarfs were compared with data available from a previously conducted study in eight Beagle dogs (four males and four females) with a mean age of 13 months (range 10-17 months) and a mean body weight of $11.8 \mathrm{~kg}$ (range 10.0-13.5 kg) (Bhatti et al., 2005). The dogs had free access to tap water and were fed a commercial dog food. They had no history of illness and had not received any medications.

The mean age of the healthy dogs did not differ significantly $(P=0.5$, independent samples $t$-test) from that in the pituitary dwarfs. The mean body weight of the healthy dogs was slightly higher $(P=0.04$, independent samples $t$ test) than in the dwarfs.

All experiments were carried out in conscious animals after an overnight fast. In the female healthy dogs, blood samples were obtained in anoestrus.

\subsection{Study design}

In all dogs, human ghrelin (MW 3370.9) (Peninsula Laboratories Inc. Belmont, CA, USA), was administered intravenously in a dose of $2 \mu \mathrm{g} / \mathrm{kg}$ body weight through an intravenous catheter. The peptide was dissolved according to the Peninsula laboratory requirements and was stored at $-20^{\circ} \mathrm{C}$. Ghrelin, in a concentration of $10 \mu \mathrm{g} / \mathrm{ml}$, was thawed before administration. For each dog a fresh vial was applied. The mean volume to be injected was $1.9 \mathrm{ml}$ for the pituitary dwarfs and $2.4 \mathrm{ml}$ for the healthy dogs.

Blood samples for the determination of plasma concentrations of GH, ACTH, cortisol, TSH, LH and PRL were collected by jugular venipuncture at $15 \mathrm{~min}$ before and 0,5 , $10,20,30$, and 45 min after ghrelin injection. Blood samples for the determination of plasma concentrations of insulin-like growth factor-1 (IGF-1) were collected by jugular venipuncture at -15 and $0 \mathrm{~min}$. The samples were immediately transferred to ice-chilled EDTA-coated tubes (GH, IGF-1, ACTH, cortisol, LH and PRL) or heparincoated tubes (TSH) and centrifuged at $4{ }^{\circ} \mathrm{C}$ for $10 \mathrm{~min}$. Plasma was stored at $-25^{\circ} \mathrm{C}$ until assayed.

\subsection{Hormone determination}

Plasma GH concentrations were determined with a homologous radioimmunoassay (RIA) (Eigenmann and Eigenmann, 1981). The intra- and inter-assay coefficients of variation were $3.8 \%$ and $7.2 \%$, respectively, and the sensitivity of the assay was $0.3 \mu \mathrm{g} / \mathrm{l}$. The degree of cross-reaction with canine PRL was $2 \%$.

Plasma ACTH concentrations were determined with an immunoradiometric assay (Nichols Institute, Wijchen, The Netherlands). The inter-assay coefficient of variation was $7.8 \%$ and the sensitivity was $0.2 \mathrm{pmol} / 1$.

Plasma cortisol concentrations were determined with a commercially available RIA (Diagnostic Products Corporation (DPC), Los Angeles, CA, USA), validated for dogs. The intra- and inter-assay coefficients of variation ranged from $3.0 \%$ to $5.1 \%$ and from $4.0 \%$ to $6.4 \%$, respectively. The sensitivity of the assay was $5.5 \mathrm{nmol} / 1$.

Plasma TSH concentrations were determined with a homologous solid-phase, two-site chemiluminiscent 
enzyme immunometric assay (Immulite ${ }^{\circledR}$ canine TSH, DPC, Los Angeles, CA, USA) according to the instructions of the manufacturer. The intra-assay coefficients of variation were $5.0 \%, 4 \%$, and $3.8 \%$ at TSH levels of $0.20,0.50$, and $2.6 \mu \mathrm{g} / 1$, respectively. The inter-assay coefficients of variation were $6.3 \%$ and $8.2 \%$ at TSH levels of 0.16 and $2.8 \mu \mathrm{g} / 1$, respectively. The sensitivity of the assay was $0.03 \mu \mathrm{g} / 1$. Cross-reactivity with FSH and LH was negligible.

Plasma LH concentrations were determined with a heterologous RIA as described previously by Nett et al. (1975). A rabbit antiserum raised against ovine LH (CSU-204), radioiodinated NIAMDD-bLH-4, and canine pituitary standard LER 1985-1 were used in this assay. The intra- and inter-assay coefficients of variation for concentrations higher than $0.5 \mu \mathrm{g} / 1$ were $2.3 \%$ and $10.5 \%$, respectively. The sensitivity of the assay was $0.3 \mu \mathrm{g} / 1$.

Plasma concentrations of PRL were determined with a previously validated heterologous RIA (Okkens et al., 1985). The intra- and inter-assay coefficients of variation were $3.5 \%$ and $11.5 \%$, respectively. The sensitivity of the assay was $0.8 \mu \mathrm{g} / 1$.

Plasma IGF-1 concentrations were determined with a heterologous RIA validated for the dog (Nap et al., 1993). The intra- and inter-assay coefficients of variation were $4.7 \%$ and $15.6 \%$, respectively, and the sensitivity of the assay was $3 \mu \mathrm{g} / 1$.

\subsection{Data processing and statistical analysis}

Basal plasma concentrations (mean of -15 and $0 \mathrm{~min}$ ) of GH, IGF-1, ACTH, cortisol, TSH, LH and PRL in the dogs with pituitary dwarfism and the healthy dogs were compared using an independent samples $t$-test to study differences between both dog groups before treatment.

Additionally, the difference between the plasma hormone concentration just before $(0 \mathrm{~min})$ injection of ghrelin and the maximal plasma hormone concentration after injection was calculated for each dog (referred to as the maximal increment) and used to capture the effect of treatment. Therefore, an independent samples $t$-test was used to study the differences in maximal increments between both dog groups.

Statistical significance was defined at $P \leqslant 0.05$. Values are expressed as mean concentration \pm SEM. Statistical analysis was performed with SPSS version 12.0 for windows (SPSS Inc., Chicago, IL, USA).

\subsection{Ethics of the study}

This study was approved by the Ethics Committee of the Faculty of Veterinary Medicine, Utrecht University.

\section{Results}

No side effects were observed during or after intravenous administration of ghrelin, neither in the German shepherd dwarfs nor in the healthy dogs.
Table 1

Mean basal ( -15 and 0 min) plasma IGF-1 (basal IGF-1) and GH (basal $\mathrm{GH})$ concentration and maximal plasma $\mathrm{GH}$ concentration after intravenous administration of ghrelin (GH max) in eight healthy Beagle dogs and in six German shepherd dogs with pituitary dwarfism

\begin{tabular}{lcclc}
\hline & & $\begin{array}{l}\text { Basal IGF-1 } \\
(\mu \mathrm{g} / \mathrm{l})\end{array}$ & $\begin{array}{l}\text { Basal GH } \\
(\mu \mathrm{g} / \mathrm{l})\end{array}$ & $\begin{array}{c}\text { GH max } \\
(\mu \mathrm{g} / \mathrm{l})\end{array}$ \\
\hline Healthy dogs & Dog 1 & 125 & 0.8 & 1.7 \\
& Dog 2 & 124 & 0.2 & 76 \\
& Dog 3 & 72 & 0.2 & 124 \\
& Dog 4 & 123 & 0.2 & 0.2 \\
& Dog 5 & 51 & 0.6 & 4.8 \\
& Dog 6 & 43 & 1.0 & 47 \\
& Dog 7 & 63 & 0.9 & 57 \\
& Dog 8 & 58 & 0.5 & 69 \\
& Dog 1 & 52 & 0.4 & 4.1 \\
& Dog 2 & 3 & 0.4 & 0.7 \\
& Dog 3 & 106 & 0.6 & 1.9 \\
& Dog 4 & 78 & 1.1 & 1.9 \\
& Dog 5 & 45 & 1.2 & 2.2 \\
& Dog 6 & 47 & 0.5 & 1.2 \\
\hline
\end{tabular}

The mean basal plasma GH concentration was not significantly different in the dogs with pituitary dwarfism $(0.7 \pm 0.1 \mu \mathrm{g} / \mathrm{l})$ and in the healthy $\operatorname{dogs}(0.5 \pm 0.1 \mu \mathrm{g} / \mathrm{l})$ and neither was the mean basal plasma IGF-1 concentration $(55 \pm 14 \mu \mathrm{g} / 1$ versus $88 \pm 13 \mu \mathrm{g} / \mathrm{l}$, respectively) (Table 1). The mean basal plasma concentrations of ACTH and cortisol in the dogs with pituitary dwarfism $(67 \pm 17 \mathrm{ng} / 1$ and $94 \pm 20 \mathrm{nmol} / 1$, respectively) did not differ significantly from those in the healthy $\operatorname{dogs}(38 \pm 6 \mathrm{ng} / 1$ and $71 \pm 15 \mathrm{nmol} / 1$, respectively). However, the mean basal plasma concentration of TSH and PRL in the dogs with pituitary dwarfism $(0.06 \pm 0.01$ and $1.3 \pm 0.2 \mu \mathrm{g} / \mathrm{l}$, respectively) were significantly lower compared with those in the healthy dogs $(0.12 \pm 0.02$ and $2.2 \pm 0.2 \mu \mathrm{g} / \mathrm{l}$, respectively). The mean basal plasma concentration of $\mathrm{LH}$ in the pituitary dwarfs $(3.7 \pm 0.6 \mu \mathrm{g} / \mathrm{l})$ was significantly higher than in the healthy dogs $(1.8 \pm 0.3 \mu \mathrm{g} / \mathrm{l})$.

Analysis of the maximal increment indicated that the mean plasma GH response after ghrelin injection was significantly lower in the dwarf dogs $(1.4 \pm 0.4 \mu \mathrm{g} / \mathrm{l}) \mathrm{com}$ pared with that in the healthy dogs $(45.3 \pm 14.8 \mu \mathrm{g} / \mathrm{l})$ (Fig. 1(a)). In none of the pituitary dwarfs, the ghrelin-induced plasma GH concentration exceeded $5 \mu \mathrm{g} / \mathrm{l}$ at any time (Table 1). However, this was also true for 3 healthy dogs. Administration of ghrelin did not affect the plasma concentrations of ACTH, cortisol, TSH, LH and PRL in either the dogs with pituitary dwarfism or in the healthy dogs (Figs. 1(b)-(f), respectively).

\section{Discussion}

Assessment of random basal plasma GH concentrations is inadequate for documentation of hyposomatotropism, because circulating $\mathrm{GH}$ concentrations in healthy dogs and pituitary dwarfs may overlap (Kooistra et al., 2000). Indeed, the results of this study illustrate the absence of a 

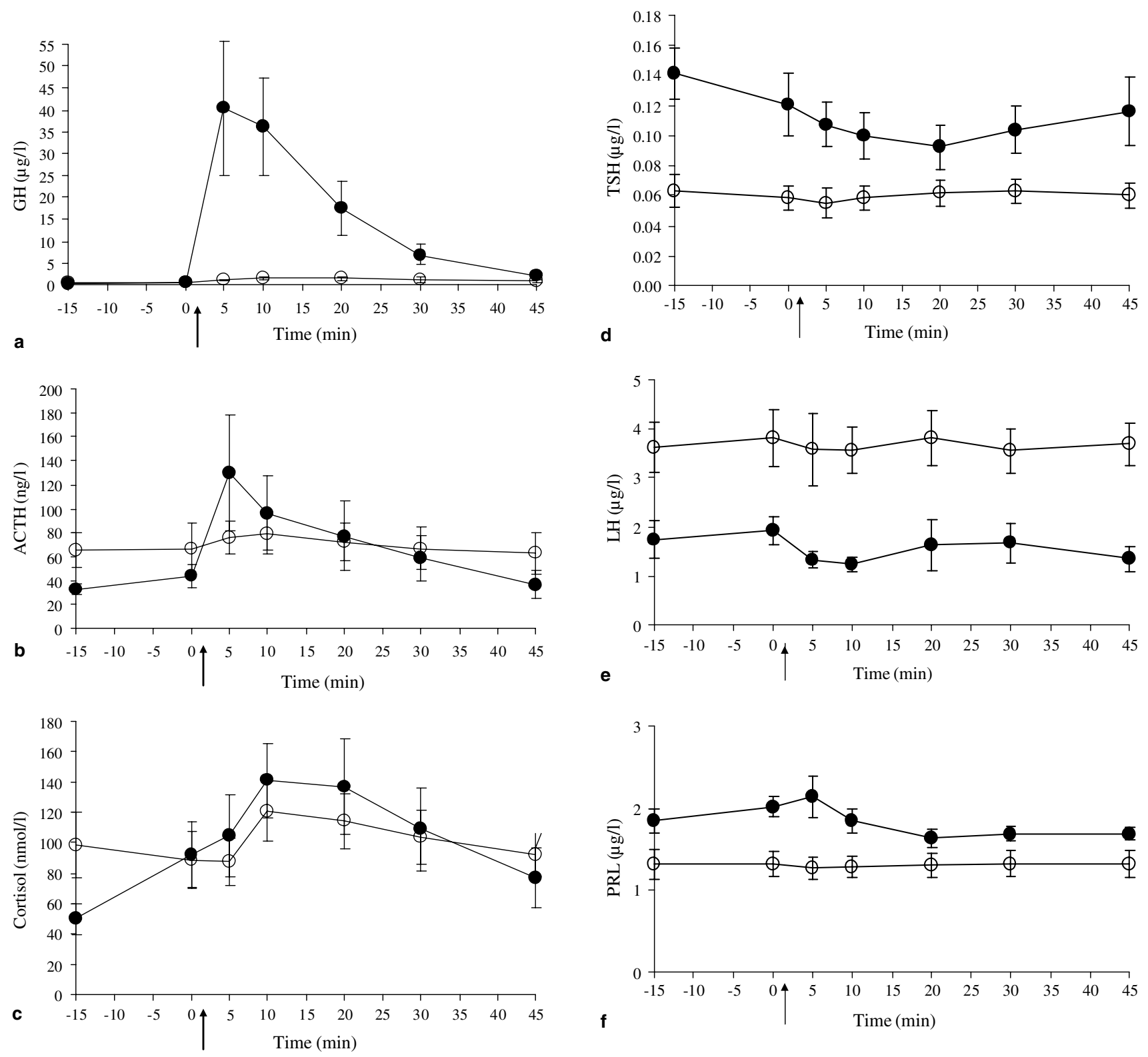

Fig. 1. (a-f): Mean $( \pm \mathrm{SEM})$ plasma concentrations of GH, ACTH, cortisol, TSH, LH, and PRL, respectively, before and after intravenous administration of $2 \mu \mathrm{g} / \mathrm{kg}$ ghrelin (arrow) in six German shepherd dogs with pituitary dwarfism $(\bigcirc)$ and in eight healthy Beagle dogs $(\bullet)$.

significant difference in basal plasma GH concentration between healthy dogs and German shepherd dogs with pituitary dwarfism. Although the plasma IGF-1 concentration represents the secretion of $\mathrm{GH}$, this concentration cannot be used to irrefutably diagnose hyposomatotropism. In GH-deficient human adults, circulating IGF-1 levels are within the reference range in about $60 \%$ of cases (Gill et al., 1998). In accordance with previous canine studies (Eigenmann et al., 1984; Rijnberk et al., 1993; Kooistra et al., 1998, 2000), the mean basal plasma IGF-1 concentration in the pituitary dwarfs was lower than that in the healthy dogs, but due to a considerable overlap this difference did not reach statistical significance.

Thus, because of comparable plasma concentrations of GH and IGF-1 between pituitary dwarfs and healthy indi- viduals, the diagnosis of GH deficiency has to be based upon the results of a stimulation test. In dogs, most $\alpha$ adrenergic drugs (such as clonidine and xylazine) or GHRH are commonly used to test the GH secretory capability of the pituitary somatotrophs. In pituitary dwarfs, there is no significant increase in plasma GH concentration after administration of one of the aforementioned GHSs (Eigenmann et al., 1984). Adverse reactions, such as sedation, bradycardia, hypotension, and collapse, may preclude the use of xylazine and clonidine, especially at high doses (Eigenmann and Eigenmann, 1981; Lothrop, 1988). Since ghrelin is a more potent GH-releaser than GHRH in young dogs, (Bhatti et al., 2005), we tested whether ghrelin can be used to diagnose canine pituitary dwarfism. In none of the dwarf dogs ghrelin administration resulted in a rise of the 
plasma GH concentration above $5 \mu \mathrm{g} / \mathrm{l}$. This finding corresponds with observations in humans with isolated childhood-onset GH deficiency, in whom the GH response to ghrelin is also markedly reduced (Aimaretti et al., 2002). However, in some of the healthy dogs the plasma GH concentration remained low after ghrelin administration as well. Thus while a ghrelin-induced plasma GH concentration higher than $5 \mu \mathrm{g} / 1$ seems to exclude GH deficiency, false-negative results may be encountered. The reason for the blunted ghrelin-induced GH response in healthy dogs remains unclear. In other species such as man, mice and rats, a similar atypical hormone response to ghrelin has not been mentioned in the literature. Stress may decrease the responsiveness of the pituitary somatotrophs to GH stimulation tests in humans (Lazarus, 1984) and may have played a role in our study.

In line with earlier findings in German shepherd dwarf dogs (Hamann et al., 1999; Kooistra et al., 2000), the basal plasma TSH and PRL concentrations in these dogs were significantly lower than those in healthy dogs. In addition, ACTH and consequently cortisol secretion seemed to be preserved in the dwarf dogs. In contrast with the study of Kooistra et al. (2000), we found that the basal plasma LH concentration was significantly higher in the dogs with pituitary dwarfism. This unexpected finding warrants further investigation of basal LH secretion in German shepherd dwarfs with combined pituitary hormone deficiency.

Treatment of this form of combined pituitary hormone deficiency in German shepherd dwarfs consists of restoring the two most important hormone deficits, i.e., TSH and GH deficiency. The secondary hypothyroid state can easily be treated by oral supplementation of synthetic L-thyroxine. GH substitution therapy in these dwarfs is less straightforward. Canine GH is not yet available for therapeutic use. Moreover, antibody formation precludes the use of biosynthetic human GH (van Herpen et al., 1994). The amino acid sequence of canine GH is identical to that of porcine GH (Ascacio-Martinez and Barrera-Saldana, 1994), but the results of treatment of pituitary dwarf dogs with porcine GH are not satisfactory (Eigenmann and Eigenmann, 1981). In addition, treatment with heterologous GH is expensive. At present, the only available treatment option consists of administration of medroxyprogesterone acetate (Kooistra et al., 1998) or proligestone (Knottenbelt and Herrtage, 2002). The GH production induced by progestins originates from foci of hyperplastic ductular epithelium in the mammary gland (Selman et al., 1994; Mol et al., 1995; van Garderen et al., 1997). In dogs, this mammary-derived GH reaches the systemic circulation (Selman et al., 1994). Unfortunately, treatment with progestins may result in undesirable side-effects, such as diabetes mellitus, cystic endometrial hyperplasia, recurrent pyoderma, and associated pruritus (Kooistra et al., 1998; Knottenbelt and Herrtage, 2002; Romagnoli and Concannon, 2003).

Based on the strong and reproducible GH-releasing effect of GHSs, these molecules, particularly if orally active, could theoretically have therapeutic usefulness in hyposomatotropism. The GHS-R type 1a is present in the pituitary and hypothalamus of several mammalian species and is distinct from the GHRH receptor (Howard et al., 1996; McKee et al., 1997; Pong et al., 1996). As GHRH is not able to stimulate the release of GH from the pituitary somatotrophs in German shepherd dogs with pituitary dwarfism (Kooistra et al., 2000), theoretically the ghrelin-activated pathway offers another treatment option. However, in line with the absence of pituitary somatotrophs, no GH response occurred and consequently ghrelin is not a candidate for the treatment of this disorder. Again theoretically, the possibility that long-term treatment with ghrelin would restore circulating GH levels in dogs with hyposomatotropism can not be ruled out. Though, long-term administration of MK-0677, a synthetic non-peptidyl GHS, was not very effective in increasing growth velocity in children with isolated GH deficiency, however they did benefit from recombinant human GH replacement therapy (Yu et al., 1998).

In humans and rats, the endocrine activity of both ghrelin and synthetic GHSs is not specific for GH. In healthy humans, intravenous administration of GHRP-6 or ghrelin also increases circulating concentrations of PRL, ACTH, and cortisol (Massoud et al., 1996; Casanueva and Dieguez, 1999; Takaya et al., 2000; Arvat et al., 2001; Ghigo et al., 2001). In rats, GHRP-6 activates the hypothalamic-pituitary-adrenal axis (Thomas et al., 1997). In contrast, in the present study ghrelin did not cause significant elevations in plasma concentrations of ACTH, cortisol, TSH, LH and PRL, neither in the healthy dogs nor in the German shepherd dwarfs.

The data of the ghrelin-stimulation test in German shepherd dwarfs were compared with those in healthy Beagle dogs. This may raise the question whether the differences in the results might be attributable to differences in breed. However, in a study of Meij et al., 1997), no breed-related variation in the response of $\mathrm{GH}$ to stimulation with GHRH was noticed in dogs with pituitary-dependent hyperadrenocorticism. Therefore the lack of response of the pituitary somatotrophs to stimulation with ghrelin can be considered abnormal in the German shepherd dwarfs. Comparison with healthy, normal-sized German shepherd dogs of a comparable age as the dwarf dogs might have been more appropriate, but these dogs were not available for endocrine testing. In addition, these dogs would have weighed considerably more than the German shepherd dwarfs and this discrepancy could also have influenced the plasma GH levels. For these reasons, healthy Beagle dogs of a comparable age and body weight were used as a control group.

It can be concluded that administration of the natural ligand of the GHS-R type 1a, i.e., ghrelin, is not able to induce a considerable rise in plasma $\mathrm{GH}$ concentration in German shepherd dogs with pituitary dwarfism. While a ghrelin-induced plasma GH concentration higher than $5 \mu \mathrm{g} / 1$ seems to exclude $\mathrm{GH}$ deficiency, false-negative results may be encountered. 


\section{Acknowledgements}

The rabbit antiserum raised against ovine LH (CSU204) and the canine pituitary standard LER 1985-1 were kindly supplied by G.D. Niswender, Colorado State University and Dr. L.E. Reichert, Albany Medical College, respectively.

The authors are grateful for the technical assistance of Mrs. D.M. Blankenstein, Mr. H.G.H. van Engelen and Mrs. J. Wolfswinkel. The critical reading of the manuscript by Prof. Dr. A. Rijnberk is highly appreciated.

\section{References}

Aimaretti, G., Baffoni, C., Broglio, F., Janssen, J.A., Corneli, G., Deghenghi, R., Van Der Lely, A.J., Ghigo, E., Arvat, E., 2002. Endocrine responses to ghrelin in adult patients with isolated childhood-onset growth hormone deficiency. Clinical Endocrinology 56, 765-771.

Andresen, E., Willeberg, P., 1976. Pituitary dwarfism in German shepherd dogs: additional evidence of simple, autosomal recessive inheritance. Nordisk Veterinaer Medicin 28, 481-486.

Arvat, E., Di Vito, L., Broglio, F., Papotti, M., Muccioli, G., Dieguez, C., Casanueva, F.F., Deghenghi, R., Cammanni, F., Ghigo, E., 2000. Preliminary evidence that ghrelin, the natural growth hormone secretagogue receptor ligand, strongly stimulates GH secretion in humans. Journal of Endocrinological Investigation 23, 493-495.

Arvat, E., Maccario, M., Di Vito, L., Broglio, F., Benso, A., Gottero, C., Papotti, M., Muccioli, G., Dieguez, C., Casanueva, FF., Deghenghi, R., Camanni, F., Ghigo, E., 2001. Endocrine activities of ghrelin, a natural growth hormone secretagogue (GHS), in humans: comparison and interactions with hexarelin, a nonnatural peptidyl GHS, and GHreleasing hormone. Journal of Clinical Endocrinology and Metabolism 86, 1169-1174.

Ascacio-Martinez, J.A., Barrera-Saldana, H.A., 1994. A dog growth hormone cDNA codes for a mature protein identical to pig growth hormone. Gene 143, 277-280.

Bednarek, M.A., Feighner, S.D., Pong, S.S., McKee, K.K., Hreniuk, D.L., Silva, M.V., Warren, V.A., Howard, A.D., Van Der Ploeg, L.H., Heck, J.V., 2000. Structure-function studies on the new growth hormone-releasing peptide, ghrelin: minimal sequence of ghrelin necessary for activation of growth hormone secretagogue receptor 1a. Journal of Medicinal Chemistry 43, 4370-4376.

Bhatti, S.F.M., De Vliegher, S.P., Van Ham, L., Kooistra, H.S., 2002. Effects of growth hormone-releasing peptides in healthy dogs and in dogs with pituitary-dependent hyperadrenocorticism. Molecular and Cellular Endocrinology 197, 97-103.

Bhatti, S.F.M., Duchateau, L., Van Ham, L.M.L., De Vliegher, S.P., Mol, J.A., Rijnberk, A., Kooistra, H.S., 2005. Effects of growth hormone secretagogues on the release of adenohypophyseal hormones in young and old healthy dogs. The Veterinary Journal, [Epub ahead of print].

Bowers, C.Y., Chang, J., Momany, F.A., Folkers, K., 1977. Effect of the enkephalins and enkephalin analogs on release of pituitary hormones in vitro. In: MacIntyre, G., Szelke, H. (Eds.), Molecular Endocrinology. Elsevier, The Netherlands, pp. 287-292.

Casanueva, F.F., Dieguez, C., 1999. Growth hormone secretagogues: physiological role and clinical utility. Trends in Endocrinology and Metabolism 10, 30-38.

Date, Y., Kojima, M., Hosoda, H., Sawaguchi, A., Mondal, M.S., Suganuma, T., Matsukura, S., Kangawa, K., Nakazato, M., 2000. Ghrelin, a novel growth hormone-releasing acylated peptide, is synthesized in a distinct endocrine cell type in the gastro intestinal tracts of rats and humans. Endocrinology 141, 4255-4261.

Eigenmann, J.E., Eigenmann, R.Y., 1981. Radioimmunoassay of canine growth hormone. Acta Endocrinologica 98, 514-520.
Eigenmann, J.E., Patterson, D.F., Froesch, E.R., 1984. Body size parallels insulin-like growth factor I levels but not growth hormone secretory capacity. Acta Endocrinologica (Copenh) 106, 448-453.

Ghigo, E., Arvat, E., Giordano, R., Broglio, F., Gianotti, L., Maccario, M., Bisi, G., Graziani, A., Papotti, M., Muccioli, G., Deghenghi, R., Camanni, F., 2001. Biologic activities of growth hormone secretagogues in humans. Endocrine Reviews 14, 87-93.

Gill, M.S., Toogood, A.A., O'Neill, P.A., Thorner, M.O., Shalet, S.M., Clayton, P.E., 1998. Urinary growth hormone (GH), insulin-like growth factor I (IGF-I), and IGF-binding protein-3 measurements in the diagnosis of adult GH deficiency. Journal of Clinical Endocrinology and Metabolism 83, 2562-2565.

Hamann, F., Kooistra, H.S., Mol, J.A., Gottschalk, S., Bartels, T., Rijnberk, A., 1999. Pituitary function and morphology in two German shepherd dogs with congenital dwarfism. Veterinary Record 144, 644 646.

Hayashida, T., Murakami, K., Mogi, K., Nishihara, M., Nakazato, M., Mondal, M.S., Horii, Y., Kojima, M., Kangawa, K., Murakami, N., 2001. Ghrelin in domestic animals: distribution in stomach and its possible role. Domestic Animal Endocrinology 21, 17-24.

Howard, A.D., Feighner, S.D., Cully, D.F., Arena, J.P., Liberator, P.A., Rosenblum, C.I., Hamelin, M., Hreniuk, D.L., Playha, O.C., Anderson, J., Paress, P.S., Diaz, C., Chou, M., Liu, K.K., McKee, K.K., Pong, S.S., Chaung, L.Y., Elbrecht, A., Dashkevicz, M., Heavens, R., Rigby, M., Sirinathsiinghji, D.J., Dean, D.C., Melillo, D.G., Van de Ploeg, L.H., 1996. A receptor in pituitary and hypothalamus that functions in growth hormone release. Science 16, 974-977.

Knottenbelt, C.M., Herrtage, M.E., 2002. Use of proligestone in the management of three German shepherd dogs with pituitary dwarfism. Journal of Small Animal Practice 43, 164-170.

Kojima, M., Hosoda, H., Date, Y., Nakazato, M., Matsuo, H., Kangawa, K., 1999. Ghrelin is a growth-hormone-releasing acylated peptide from stomach. Nature 402, 656-660.

Kooistra, H.S., Voorhout, G., Selman, P.J., Rijnberk, A., 1998. Progestininduced growth hormone $(\mathrm{GH})$ production in the treatment of dogs with congenital GH deficiency. Domestic Animal Endocrinology 15, 93-102.

Kooistra, H.S., Voorhout, G., Mol, J.A., Rijnberk, A., 2000. Combined pituitary hormone deficiency in German shepherd dogs with dwarfism. Domestic Animal Endocrinology 19, 177-190.

Lantinga-van Leeuwen, I.S., Mol, J.A., Kooistra, H.S., Rijnberk, A., Breen, M., Renier, C., van Oost, B.A., 2000a. Cloning of the canine gene encoding transcription factor Pit-1 and its exclusion as candidate gene in a canine model of pituitary dwarfism. Mammalian Genome 11, 31-36.

Lantinga-van Leeuwen, I.S., Kooistra, H.S., Mol, J.A., Renier, C., Breen, M., van Oost, B.A., 2000b. Cloning, characterization, and physical mapping of the canine Prop-1 gene (PROP1): exclusion as a candidate for combined pituitary hormone deficiency in German shepherd dogs. Cytogenetics and Cell Genetics 88, 140-144.

Lazarus, L., 1984. A guide to diagnosis. In: Donald, R.A. (Ed.), Endocrine Disorders. Marcel Dekker, Inc., New York, p. 273.

Lothrop, C.D., 1988. Pathophysiology of growth-hormone responsive dermatosis. Compendium on Continuing Education for the Practicing Veterinarian 10, 1346

Massoud, A.F., Hindmarsh, P.C., Brook, D.G.D., 1996. Hexarelininduced growth hormone, cortisol and prolactin release: a doseresponse study. Journal of Clinical Endocrinology and Metabolism 81, 4338-4341.

McKee, K.K., Palyha, O.C., Feighner, S.D., Hreniuk, D.L., Tan, C.P., Phillips, M.S., Smith, R.G., Van der Ploeg, L.H., Howard, A.D., 1997. Molecular analysis of rat pituitary and hypothalamic growth hormone secretagogue receptors. Molecular Endocrinology 11, 415-423.

Meij, B.P., Mol, J.A., Bevers, M.M., Rijnberk, A., 1997. Alterations in anterior pituitary function of dogs with pituitary-dependent hyperadrenocorticism. Journal of Endocrinology 154, 505-512.

Mol, J.A., Henzen-Logmans, S.C., Hageman, P., Misdorp, W., Blankenstein, M.A., Rijnberk, A., 1995. Expression of the gene encoding 
growth hormone in the human mammary gland. Journal of Clinical Endocrinology and Metabolism 80, 3094-3096.

Nap, R.C., Mol, J.A., Hazewinkel, H.A., 1993. Age-related plasma concentrations of growth hormone $(\mathrm{GH})$ and insulin-like growth factor I (IGF-I) in Great Dane pups fed different dietary levels of protein. Domestic Animal Endocrinology 10, 237-247.

Nett, T.M., Akbar, A.M., Phemister, R.D., Holst, P.A., Reichert, L.E., Niswender, G.D., 1975. Levels of luteinizing hormone, estradiol and progesterone in serum during the estrous cycle and pregnancy in the Beagle bitch. Proceedings of the Society for Experimental Biology and Medicine 148, 134-139.

Okkens, A.C., Dieleman, S.J., Bevers, M.M., Willemse, A.H., 1985. Evidence for the non-involvement of the uterus in the lifespan of the corpus luteum in the cyclic dog. Veterinary Quarterly 7, $169-173$.

Peino, R., Baldelli, R., Rodriguez-Garcia, J., Rodriguez-Segade, S., Kojima, M., Kangawa, K., Arvat, E., Ghigo, E., Dieguez, C., Casanueva, F.F., 2000. Ghrelin-induced growth hormone secretion in humans. European Journal of Endocrinology 143, 11-14.

Pong, S.S., Chaung, L.Y.P., Dean, D.C., Nargund, R.P., Patchett, A.A., Smith, R.G., 1996. Identification of a new G-protein-linked receptor for growth hormone secretagogues. Molecular Endocrinology 10, 57 61.

Plotsky, P.M., Vale, W., 1985. Patterns of growth hormone-releasing factor and somatostatin secretion into the hypophysial-portal circulation of the rat. Science 230, 461-463.

Rijnberk, A., van Herpen, H., Mol, J.A., Rutteman, G.R., 1993. Disturbed release of growth hormone in mature dogs: a comparison with congenital growth hormone deficiency. Veterinary Record 27, 542-545.

Romagnoli, S., Concannon, P.W., 2003. Clinical use of progestins in bitches and queens: a review. In: Concannon, P.W., England, G., Verstegen, J., Linde-Forsberg, C. (Eds.), Recent Advances in Small
Animal Reproduction. International Veterinary Information Service, Ithaca, NY, pp. 1-17 (www.ivis.org) .

Selman, P.J., Mol, J.A., Rutteman, G.R., van Garderen, E., Rijnberk, A., 1994. Progestin-induced growth hormone excess in the dog originates in the mammary gland. Endocrinology 134, 287-292.

Takaya, K., Ariyasu, H., Kanamoto, N., Iwakura, H., Yoshimoto, A., Harada, M., Mori, K., Komatsu, Y., Usui, T., Shimatsu, A., Ogawa, Y., Hosoda, K., Akamizu, T., Kojima, M., Kangawa, K., Nakao, K., 2000. Ghrelin strongly stimulates growth hormone release in humans. Journal of Clinical Endocrinology and Metabolism 85, 4908-4911.

Thomas, G.B., Fairhall, K.M., Robinson, I.C.A.F., 1997. Activation of the hypothalamo-pituitary-adrenal axis by the growth-hormone $(\mathrm{GH})$ secretagogue, GH-releasing peptide-6, in rats. Endocrinology 138, $1585-1591$.

Tomasetto, C., Wendling, C., Rio, M.C., Poitras, P., 2001. Identification of cDNA encoding motilin related peptide/ghrelin precursor from dog fundus. Peptides 22, 2055-2059.

van Garderen, E., de Wit, M., Voorhout, W.F., Rutteman, G.R., Mol, J.A., Nederbragt, H., Misdorp, W., 1997. Expression of growth hormone in canine mammary tissue and mammary tumors. Evidence for a potential autocrine/paracrine stimulatory loop. American Journal of Pathology 150, 1037-1047.

van Herpen, H., Rijnberk, A., Mol, J.A., 1994. Production of antibodies to biosynthetic human growth hormone in the dog. Veterinary Record 134, 171.

van Oost, B.A., Versteeg, S.A., Imholz, S., Kooistra, H.S., 2002. Exclusion of the lim homeodomain gene LHX4 as a candidate gene for pituitary dwarfism in German shepherd dogs. Molecular and Cellular Endocrinology 29, 57-62.

Yu, H., Cassorla, F., Tiulpakov, A., 1998. A double blind placebocontrolled efficacy trial of an oral growth hormone $(\mathrm{GH})$ secretagogue (MK-0677) in GH deficient (GHD) children. Endocrine Society 1998 Abstract Book, p. 8 . 